\title{
Use the Extended Activated Sludge Process to Remove Triclosan (TCS) from Wastewater Treatment Plant
}

\author{
Mosstfa MAAROOF ${ }^{1}$, Yağmur UYSAL ${ }^{2 *}$ \\ ${ }^{1}$ Kahramanmaraş Sütçü İmam Üniversitesi, Biyomühendislik ve Bilimler Bölümü, Kahramanmaraş, Türkiye \\ ${ }^{2}$ Kahramanmaraş Sütçü İmam Üniversitesi, Çevre Mühendisliği, Kahramanmaraş, Türkiye
}

\begin{abstract}
The antibacterial personal care product Triclosan (TCS), is a broad spectrum antibacterial. It has been used for more than 40 years as an antiseptic, disinfectant or preservative in clinical settings, and in the various consumer products including cosmetics, plastic materials and toys. It has lately been determined in the sources of the aquatic environment; its potential effect on ecosystems. The contaminants can reach the soil and aquatic environment through land application of wastewater effluent and agricultural runoff, and then reach to humans through the food chain. Triclosan is used worldwide on a large scale especially in many personal care products, like toothpaste, shampoo and soap. In this study, the removal of Triclosan was investigated in an extended activated sludge process set in a laboratory-scale reactor. Activated sludge biomass used in the reactor was obtained from Gaziantep wastewater treatment plant. The analytical method based on solid-phase extraction (SPE) followed by high Performance Liquid Chromatography (HPLC) was used for the determination of Triclosan in extended activated sludge effluent. Reactor was operated in different HRTs and Triclosan removal efficiency was obtained as 92.5\%, 95.4\%, 99.1\% and 99.9\% for different HRT values of $18 \mathrm{~h}, 24 \mathrm{~h}, 48 \mathrm{~h}$, and 52h, respectively.
\end{abstract}

Keywords: Activated Sludge, Biological Treatment, Removal, Triclosan, Wastewater

\section{INTRODUCTION}

The activated sludge process is a suspended culture system that has been use in biological wastewater treatment since the early 1900s. The process derives its name from the fact that secondary settled sludge containing living or active microorganisms returned to the reactor to increase the available biomass and to speed up the biological reactions. It may be either a completely mixed or plug flow process $[1,2]$. The extended aeration was used in this study (Fig. 1), that is a modification of the activated sludge process in which aeration time is increased to about $18-24 \mathrm{~h}$ and has high mixed liquor suspended solids between 3500-5000 mg/L [3].

\section{Flow sheet of an extended aeration system}

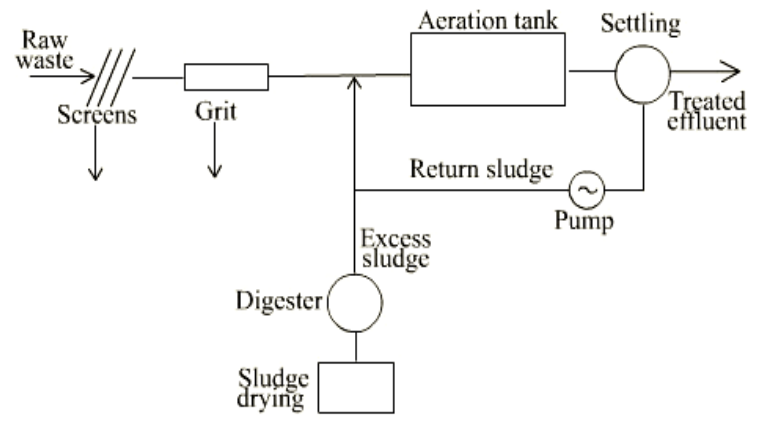

Figure 1. The extended activated sludge process.
Triclosan (5-chloro-2-(2,4-dichloro-phenoxy)phenol, a broad spectrum antibacterial, was first synthesized by Ciba-Geigy Company, Switzerland, under its trade name IRGASAN DP300 [4]. Triclosan is an antimicrobial agent that has been used for more than 40 years as an antiseptic, disinfectant or preservative in clinical settings, in various consumer products including cosmetics, plastic materials, toys, etc. It has also been shown to be Eco-toxic, particularly to algae in aquatic environments [5]. Additionally, it has been shown to interfere with the cycling of nitrogen in natural systems $[6,7]$.

Triclosan is bacteriostatic at low concentrations, but higher levels are bactericidal [8, 9]. At sub lethal concentrations it works by blocking the active site of the enoyl-acyl carrier protein reductase enzyme (ENR), which is an essential enzyme in fatty acid synthesis in bacteria [10]. Therefore it prevents the bacteria from synthesizing fatty acid, which is necessary for building cell membranes and for reproducing. Since humans do not have this ENR enzyme, triclosan has long been thought to be fairly harmless to them. It is a very potent inhibitor, and only a small amount is needed for powerful antibacterial action $[11,12]$. It is suggested to act through multiple nonspecific mechanisms including membrane damage [13].

Because of the high antimicrobial effectiveness, and popularity of triclosan has continuously increased over the last 40 years [14, 23]. For example, around 350 tons of triclosan are presently used as antimicrobial 
substance in many products in Europe, such as pharmaceutical and personal care products [15]. Triclosan is used as a built-in antimicrobial product protection (trade name of Microban $\AA$ ), in antimicrobial solutions for consumer as industrial or medical products. The technology of triclosan is engineered into a breadth of materials including polymers, textiles, coatings, ceramics, paper and adhesives. Triclosan controls microbial growth and odors within the impregnated surface but does not offer the user any significant protection from infectious microbes on the exterior surfaces of those items. This could potentially create a false sense of security, and cause the user to relax other efforts to keep surfaces clean [16]. Table 1 shows the chemical properties of Triclosan.

The present study was aimed to developing a method that using an extended activated sludge process to remove triclosan from wastewater having different concentrations of this chemical and to find out what is the fate of microorganisms at these concentrations studied.

Table 1. The chemical properties of Triclosan

\begin{tabular}{|c|c|}
\hline INCI Name & Triclosan \\
\hline $\begin{array}{l}\text { Chemical } \\
\text { Name }\end{array}$ & 2,4,4'-trichloro-2'-hydroxy-diphenylether \\
\hline $\begin{array}{c}\text { Scientific } \\
\text { name }\end{array}$ & (5-chloro-2-(2,4-dichloro-phenoxy)-phenol \\
\hline $\begin{array}{l}\text { Trade } \\
\text { Names }\end{array}$ & $\begin{array}{c}\text { Irgasan }{ }^{\circledR} \text { DP300, Irgasan }{ }^{\circledR} \text { PG60, } \\
\text { Irgacare } \AA \text { MP, Irgacare }{ }^{\circledR} \text { CF100, } \\
\text { Irgacide } \AA \text { LP10, ; Cloxifenolum, Irgagard } \AA \\
\text { B 1000, Lexol 300, Ster-Zac }\end{array}$ \\
\hline $\begin{array}{l}\text { Molecular } \\
\text { Formula }\end{array}$ & $\mathrm{C}_{12} \mathrm{H}_{7} \mathrm{C}_{13} \mathrm{O}_{2}$ \\
\hline $\begin{array}{c}\text { Molecular } \\
\text { Weight }\end{array}$ & 289.5 \\
\hline $\begin{array}{c}\text { Physical } \\
\text { form }\end{array}$ & White crystalline powder \\
\hline $\begin{array}{l}\text { Chemical } \\
\text { structure }\end{array}$ & $\mathrm{OH}$ \\
\hline
\end{tabular}

Recently, some studies have been presented in the literature to try the removal of triclosan in wastewater treatment plants (WWTPs) at Europe. These WWTPs used primary settling and activated sludge in their treatment. They observed that triclosan had high removal rates in the range of $73-58 \%$. [17]. It has also been experimentally proven that triclosan does not biodegrade under anoxic or anaerobic conditions [18]. The biodegradation of triclosan by ammonia-oxidizing bacteria was also studied in another study, and they reported that triclosan was biodegraded by this bacteria of Nitrosomonas europaea. However, they also noted that there was a reduction in the nitrate production because of competitive behavior or toxicity effects of triclosan [19].

The fate of triclosan in a conventional activated sludge process was studied another researchers, and they observed that up to 85-95\% of the influent triclosan was biodegraded and $1.5-4.5 \%$ of its sorbed to sludge. They concluded that triclosan was biodegradable in both high and low concentrations in activated sludge process. They showed that acclimation of the microorganisms is crucial for biodegradation of triclosan [20].

\section{EXPERIMENTAL}

\subsection{Activated Sludge Samples}

In the experiments, five aerobic batch bioreactors were set in the laboratory and operated. The activated sludge sample was taken from Gaziantep WWTP. It is serving about $1,150,000 \mathrm{PE}$, and is designed as biological treatment using an activated sludge process. The plant has $230,000 \mathrm{~m} 3 /$ day flow rate, and is operated with a low solids retention time (SRT) of 2-4 days. The sludge samples used in the present study were brought to the laboratory immediately, and inoculated to the bioreactors. Bioreactors were operated for 3 months to acclimate microorganisms to the laboratory conditions and to obtain biomass amount that needed for the study by feeding synthetic culture solution daily and aeration (Table 2). Five aeration pumps were used for getting the dissolved oxygen concentration of $5 \mathrm{mg} / \mathrm{L}$. When MLSS concentration reached to more than $5000 \mathrm{mg} / \mathrm{L}$, we started to add triclosan starting the lowest concentration of $0.01 \mathrm{mg} / \mathrm{L}$.

\subsection{Chemicals and Materials}

Triclosan obtained from Çağlayan Kimya ve İnş. San. Tic. A.Ş. (99\% purity). Acetonitrile and methanol for HPLC grade were from Sigma-Aldrich ${ }^{\circledR}$ (United States) and phosphate buffer from Merck (Germany). Water obtained from Milli-RX apparatus (Millipore, USA) was used to prepare solutions and buffers, which were filtered through $0.45 \mu \mathrm{m}$ Millipore filters prior to use. The sample solutions were filtered through $0.2 \mu \mathrm{m}$ Minisart ${ }^{\circledR}$ SRP15 Syringe Filters 17559Q (Orange Scientific, Waterloo, Belgium) before the injection into the chromatograph. 
Table 2. Composition of the synthetic culture solution

\begin{tabular}{|c|c|c|}
\hline Chemicals & $(\mathbf{m g} / \mathbf{L})$ & $\begin{array}{c}\text { Company } \\
\text { produced }\end{array}$ \\
\hline $\mathrm{MgSO}_{4} 7 \mathrm{H}_{2} \mathrm{O}$ & 60.9 & Sigma-Aldrich ${ }^{\circledR}$ \\
\hline $\mathrm{NaHCO}_{3}$ & 218.75 & Merck \\
\hline $\mathrm{NH}_{4} \mathrm{Cl}$ & 38.2 & Tekkim \\
\hline Yeast extract & 209.7 & Merck \\
\hline Peptone & 184.68 & Sigma-Aldrich ${ }^{\circledR}$ \\
\hline $\mathrm{CH}_{3} \mathrm{COONa}_{3} \mathrm{H}_{2} \mathrm{O}$ & 130.8 & Sigma-Aldrich ${ }^{\circledR}$ \\
\hline $\mathrm{KH}_{2} \mathrm{PO}_{4}$ & 35.1 & Sigma-Aldrich ${ }^{\circledR}$ \\
\hline $\mathrm{CaCl}_{2} 2 \mathrm{H}_{2} \mathrm{O}$ & 70 & Merck \\
\hline $\mathrm{NaHCO}_{3}$ & 218.75 & Merck \\
\hline
\end{tabular}

\subsection{Batch Reactor System}

A series of batch bioreactors were used in this study and their treatment performances were investigated by measuring influent and effluent concentrations of COD, suspended solids (MLSS) and oxygen uptake rate (OUR). The initial MLSS and COD concentrations in the reactors were maintained in the range of $4000-5000 \mathrm{mg} / \mathrm{L}$ and $900-1120 \mathrm{mg} / \mathrm{L}$, respectively. DO concentrations of reactors were controlled continuously and also maintained at $5 \pm 0.2$ [21]. The reactors were operated for $60 \mathrm{~h}$ period under in the batch mode and samples were collected at every $12 \mathrm{~h}$ time interval. $\mathrm{pH}, \mathrm{COD}, \mathrm{MLSS}$, MLVSS, DO, OUR and Sludge Volume Index (SVI) measurements were made in the samples collected from the reactors. The operational conditions of the bioreactors were shown in Table 3 .

Table 3. Operational conditions of the bioreactors

\begin{tabular}{|c|c|c|c|c|}
\hline Bioreactors & A & B & C & D \\
\hline pH & 7.1 & 6.9 & 7.4 & 7.2 \\
\hline D.O (mg/L) & 4.8 & 5.1 & 4.9 & 5.3 \\
\hline MLSS (mg/L) & 5142 & 5283 & 4971 & 5036 \\
\hline MLVSS (mg/L) & 4215 & 4230 & 3768 & 3957 \\
\hline $\begin{array}{c}\text { F/M gCOD/g } \\
\text { MLSS/ day }\end{array}$ & 0.197 & 0.212 & 0.185 & 0.198 \\
\hline SVI (ml/g) & 89 & 89.5 & 92 & 94 \\
\hline $\begin{array}{c}\text { OUR (mg/L O2 / } \\
\text { h }\end{array}$ & 25 & 27 & 26 & 27.5 \\
\hline COD in (mg/L) & 900 & 1057 & 998 & 1083 \\
\hline COD out (mg/L) & 153 & 204 & 162 & 218 \\
\hline
\end{tabular}

\subsection{Preparation of Standards and Calibration Curves}

The triclosan stock solution was prepared by dissolving $25 \mathrm{mg}$ of pure triclosan in $250 \mathrm{~mL}$ of methanol to achieve $100 \mathrm{ppm}$ concentration after that Calibration standards were prepared by dilution of triclosan standard at the following concentrations: 0.1, 0.2, 0.5, 1, 2, 5 and $10 \mathrm{ppm}$ (Fig. 2). All standards were kept at $3 \pm 1^{\circ} \mathrm{C}[21$, 22].

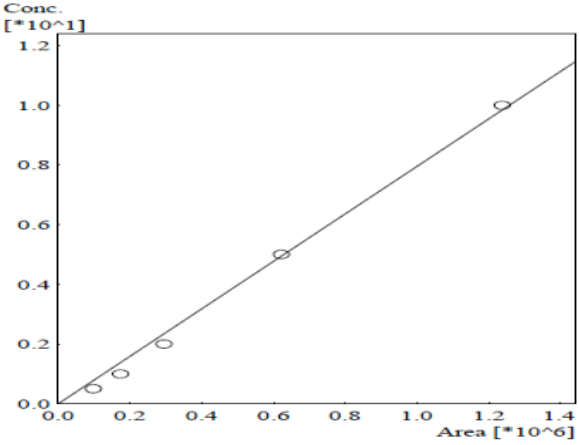

Figure 2. Calibration curve for Triclosan used in the HPLC measurements

\subsection{The Solid Phase Extraction}

After centrifugation of samples which was pulled from bioreactors having different hydraulic retention times, isolated by solid phase extraction using $3 \mathrm{mg}$ Oasis hydrophilic-lipophilic balance cartridges (Waters, United Kingdom). The samples were pre-filtered through glass fiber filters (Scheicher and Schuell). The cartridges were preconditioned with $1 \mathrm{~mL}$ methanol and $1 \mathrm{~mL}$ of ultra-pure water. The samples were drawn through the cartridges at an approximate flow rate of $1 \mathrm{~mL} / \mathrm{min}$. The cartridges were washed with $1 \mathrm{~mL} \mathrm{5 \%}$ methanol to remove any loosely bound contaminants, and then they were eluted with $2 \mathrm{~mL}$ methanol [23].

\subsection{Liquid Chromatography}

Samples were analyzed by HPLC with DAD, C18 Colum $(250,6.6,5 \mu \mathrm{m})$ Shimadzu LC 20 AT. The method summarized in Table 4 was developed as a part of this work. Triclosan, with a purity of $99.5 \%$, was used to produce HPLC standards [24]. The method was successfully applied to the determination of triclosan in the samples.

Table 4. The method for HPLC to determine Triclosan

\begin{tabular}{|c|c|}
\hline Chemical & Triclosan \\
\hline Mobil phase & $\mathrm{ACN}: \mathrm{H}_{2} \mathrm{O}$ \\
& $90: 10$ \\
\hline Flow rate & $1 \mathrm{~L} / \mathrm{min}$ \\
\hline Total time & $7 \mathrm{~min}$ \\
\hline Temperature & $40 \mathrm{C}^{\circ}$ \\
\hline Retention time & $4 \mathrm{~min}$ \\
\hline
\end{tabular}

\section{RESULTS and DISCUSSION}

As stated before, the experimental work was divided into five groups according to the HRT and the operating conditions of the reactors. The objective for this research was to determine the ability of extended activated sludge processes to remove the more widely used personal care products, triclosan because it is pollutant disturbing aquatic environment causing a lot of ecological problems. And to learn what is the fate 
capacity of triclosan by aerobic microorganisms when they exposure to different concentrations of triclosan.

\subsection{LC/MS Analysis of Triclosan}

Establishing the chromatographic retention time to select an appropriate precursor ion for the analytic was the initial step for developing a LC/MS method. The mobile phase was chosen after several trials with methanol, acetonitrile, water and buffer solutions. A mobile phase consisting of acetonitrile and water (90:10) $(\mathrm{v} / \mathrm{v})$ was selected to achieve maximum separation and sensitivity. A flow rate of $1.0 \mathrm{~mL} / \mathrm{min}$ gave an optimal signal to noise ratio with a reasonable separation time. Using a reversed-phase $\mathrm{C} 18$ column, the retention time for triclosan was observed to be $4.0521 \mathrm{~min}$, total time of analysis was less than $6 \mathrm{~min}$, and the maximum absorption of triclosan was detected at $210 \mathrm{~nm}$. Thus, this wavelength was chosen for the analysis. The chromatogram at $210 \mathrm{~nm}$ showed a complete resolution of all peaks (Figure 3).

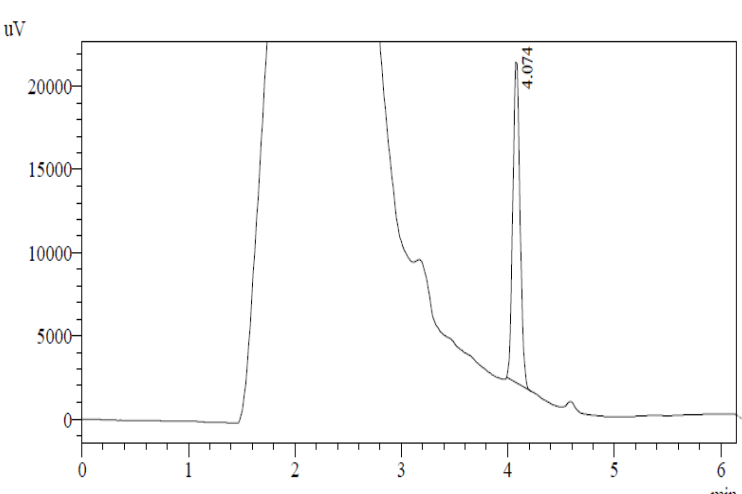

Figure 3. Detection of Triclosan by HPLC

\subsection{Determination of Triclosan}

Standard solutions of triclosan in the range of 0.1 to $10 \mathrm{mg} / \mathrm{L}$ were prepared with methanol in this study. The calibration line established was $\mathrm{Y}=(910.2 \pm 8.0) \mathrm{X}+(593.6 \pm 632.1)$ with $\mathrm{R} 2=0.997$, where $\mathrm{Y}$ and $\mathrm{X}$ equaled peak area and concentration of triclosan, respectively.

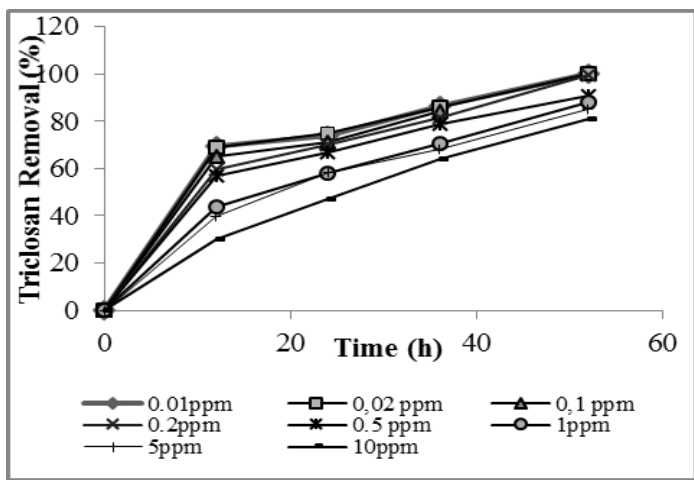

Figure 4. Triclosan removal (\%) with time

\subsection{COD Removal}

The percentage removal of triclosan in the bioreactors were calculated from the total concentration (dissolved and particulate) in activated sludge water ( $\mathrm{C}$ inf) and final effluent (Ceff) according Eq. (1)

$$
\operatorname{removal}(\%)=C_{\text {inf }}-C_{e f f} \div C_{\text {lnf }} \times 100
$$

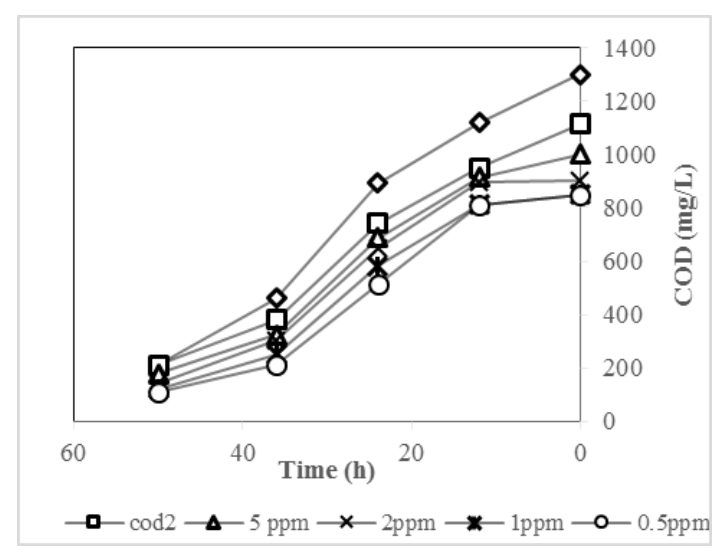

Figure 5. COD removal with time

\section{CONCLUDED}

An analytical method was developed, optimized and validated for the determination of the personal care products triclosan, by developing the activated sludge process (extended) and SPE with LC /MS analysis.

The results of the present work exhibit that extended activated sludge reactor can be used for enhanced the removal of triclosan, which would be further increased by addition of more aeration time. The present reactor performed as extended activated sludge system, where appreciable COD loading in order of $1200 \mathrm{mg} / \mathrm{L}$ can be applied to output more than $85 \%$ COD removal efficiency under purely suspended growth condition, which could be further improved upon addition of biodegradation.

Beside that the results of the study explain that triclosan were widely added in personal care products as the antibacterial agents in world.

To assess the associate risks, the concentrations of triclosan in wastewater as well as their environmental fates needed to be determined in WWTPs since it can be expected that triclosan will not only be found in household but will also be detected in the following aquatic environments, also concluded that triclosan did not disrupt the activated sludge processes in the WWTP, not even in high concentrations.

The efficiency of the COD removal depends directly on mean residence time, and the amount of air processed, where all the organic material is oxidized by 
oxygen, as well as, the COD removal initially increased monotonically, and then decreased with an increase in air velocity.

\section{REFERENCES}

[1]. Nakada, N., Yasojima, M., Okayasu, Y., Komori, K., and Suzuki, Y. 2010. Mass balance analysis of triclosan, diethyltoluamide, crotamiton and carbamazepine in sewage treatment plants, Water Science and Technology; 2010, Vol. 61 Issue 7, p1739.

[2]. Gebara, F., 1999. "Activated sludge biofilm wastewater treatment system", Water Research, 33,1, p p. $230-238$.

[3]. Activated sludge process control manual 2004. US-EPA, SESD, Athens, GA.

[4]. Bhargava, H. N., and Leonard, P. A., 1996. Triclosan: applications and safety. American Journal of Infection Control, 24, 209-218.

[5]. Tatarazako, N., Ishibashi, H., Teshima, K., Kishi, K., and Arizono, K., 2004. Effects of triclosan on various aquatic organisms. Environ. Sci. 11, 133140.

[6]. Fernandes, M., Shareef, A., Karkkainen, M., and Kookana, R., 2008. The occurrence of endocrine disrupting chemicals and triclosan in sediments of Barker Inlet, South Australia. A Report prepared for the Adelaide and Mount Lofty Ranges Natural Resources Management Board. SARDI Publication Number F2008/001026-1. South Australian Research and Development Institute (Aquatic Sciences), Adelaide. http://www.sardi.sa.gov.au

[7]. Waller, N. J., Kookana, R. S., 2009. Effect of triclosan on microbiological activity in Australian soils. Environ. Toxicol. Chem. 28:65-70.

[8]. Suller, M.T.E., and Russell, A. D., 1999. Antibiotic and biocide resistance in methicillinresistant Staphylococcus aureus and vancomycin resistant Enterococcus. J. Hosp. Infect. 43:281291.

[9]. Suller, M.T.E., and Russell, A.D., 2000. Triclosan and antibiotic resistance in Staphylococcus aureus. J. Antimicrobial Chemother 46:11-18.

[10]. Levy, C. W., Roujeinikova, A., Sedelnikova, S., 1999. Molecular basis of triclosan activity. Nature 398, 383-4.

[11]. Heath, R.J., White, S.W., Rock, C.O., 2002. Inhibitors of fatty acid synthesis as antimicrobial chemotherapeutics. Appl. Microbiol. Biotechnol. 58:695-703.
[12]. Zhang, S., Zhang, Q., Darisaw, S., Ehie, O., Wang, G., 2007. Simultaneous quantification of polycyclic aromatic hydrocarbons (PAHS), polychlorinated biphenyls (PCBS), and pharmaceuticals and personal care products (PPCPS) in Mississippi River water, in New Orleans, Louisiana, USA. Chemosphere 66:10571069.

[13]. Gilbert, P., Allison, D.G., McBain, A.J., 2002. Biofilms in vitro and in vivo: do singular mechanisms imply cross-resistance. J. Appl. Microbiol 92:S98-110.

[14]. Singer, H., Müller, S., Tixier, C., Pillonel, 2002. Triclosan: occurrence and fate of a widely used biocide in the aquatic environment: field measurements in wastewater treatment plants, surface waters, and lake sediments. Environ. Sci. Technol. 36:4998-5004

[15]. Ciba Specialty Chemical, 1998. Fact Sheet, PEC Calculation of Triclosan. Basle, Switzerland.

[16]. Glasser, A., 2004. Triclosan, the ubiquitous antibacterial agent. Pesticides and You. Beyond Pesticides/National Coalition against the Misuse of Pesticides. Vol.24, No.3, 12.

[17]. Paxéus, N., 2004. Removal of selected nonsteroidal anti-inflammatory drugs (NSAIDs), gemifibrozil, carbamazepine, beta-blockers, trimethoprim and triclosan in conventional wastewater treatment plants in five EU countries and their discharge to the aquatic environment. Water Science and Technology, Volume 50, pp. 153-260.

[18]. Chen, X., Lund Nielsen, J., Furgal, K., Liu, Y., Lolas, IB., and Bester, K., 2011. Biodegradation of triclosan and formation of methyl-triclosan in activated sludge under aerobic conditions. Chemosphere, Volume 84, pp. 452-456.

[19]. Roh, H., Subramanya, N., Zhao, F., Yu, C-P., Sandt, J. and Chu, K.H., 2009. Biodegradation potential of wastewater micro pollutants by ammonia-oxidizing bacteria. Chemosphere, Volume 77, pp. 1084-1089.

[20]. Federle, T. W., Kaiser, S. K. and Nuck, B. A., 2002. Fate and effects of triclosan in activated sludge. Environmental Toxicology and Chemistry, Volume 21, pp. 1330-1337.

[21]. US Code of Federal Regulations, Title 40, Part 136, Appendix B, Definition and procedure for the determination of the method detection limit, revision 1.11

[22]. Ahlgren, P., 2012. Biodegradation of potentially harmful compounds in wastewater treatment, 
Master Thesis, Aalto University, schools of technology ,115s.

[23]. Shang, D., Kim, M., Haberl, M. and Legzdins, A., J. Chrom. A., 2013. Development of a rapid liquid chromatography tandem mass spectrometry method for screening of trace naphthenic acids in aqueous environments. 1278, 98-107.

[24]. Tixier, C., Singer, H.P., Canonica, S., Mqller, S.R., 2002. Photo transformation of triclosan in surface waters: a relevant elimination process for this widely used biocide-laboratory studies, field measurements, and modeling. Environ. Sci. Technol. 36:3482-9.

[25]. Matuszewski, B.K., Constanzer, C.M., ChavezEng, C.M., 2002. Strategies for the assessment of matrix effect in quantitative bio analytical methods based on HPLC-MS/MS. Anal Chem. 75:3019-30.

[26]. McAvoy, D.C., Schatowitz, B, Jacob, M., Hauk, A., Eckhoff, W.S., 2002. Measurement of triclosan in wastewater treatment systems. Environ Toxicol Chem. 2:1323-9. 